\title{
Analysis of the Competitiveness and Complementarity of China-Ukraine Trade Cooperation under the Background of "Belt and Road"
}

\author{
Ying Wang ${ }^{1, a^{*}}, \mathrm{Ze} \mathrm{Tian}^{2, \mathrm{~b},}$ and Shenyue $\mathrm{Xia}^{3, \mathrm{c}}$ \\ ${ }^{1}$ School of Business Administration,Hohai University, Changzhou,China \\ ${ }^{2}$ The director of the institute of low-carbon economy at hohai university, Changzhou,China \\ ${ }^{3}$ School of Business Administration, Hohai University, Changzhou,China \\ a18261195216@163.com, btianze21@126.com, c15161158727@163.com
}

${ }^{*}$ Corresponding author

Keywords: Belt and Road; Ukraine; competitiveness; complementarity

\begin{abstract}
This paper selects the Trade Intensity Index (TII), Intra-Industry Trade Index and Revealed Comparative Advantage Index (RCA) to analyze the competitiveness and complementarity of Sino-Ukrainian trade in goods, and concludes that the trade complementarity between the two countries is dominant. To this end, it is proposed to expand the scale of trade between China and Ukraine, broaden the types of export products; strengthen cooperation in agriculture; promote direct investment by domestic enterprises in Ukraine, and jointly recommend the Zhongwu Industrial Park.
\end{abstract}

\section{Introduction}

In September and October 2013, during his visit to Central Asia and Southeast Asian countries, President Xi Jinping successively proposed a major initiative to jointly build the "Silk Road Economic Belt" and the "21st Century Maritime Silk Road", which received wide attention from the international community. As the second largest country in Europe, Ukraine is the third largest grain exporter in the world. It has the reputation of "European granary" and is an important member of the "One Belt, One Road"initiative. It is the first to announce its support for "Belt and Road" initiative among European countries.In order to further deepen the trade cooperation between the two countries, it is of profound theoretical and practical significance to study the competitiveness and complementarity of trade between the two countries.

\section{Status of trade cooperation between China and Ukraine}

Since the establishment of diplomatic relations between China and Ukraine on January 4, 1992, despite the changes in the political situation in Ukraine, the two countries have always maintained close trade cooperation. After decades of development, the trade volume between the two countries has been steadily improving, and the trade structure has been continuously improved. According to the UN COMTRADE database, as of 2017, China has become Ukraine's second largest trading partner, second only to Russia. The total trade volume between China and Ukraine reached US\$7.772 billion, accounting for $8.37 \%$ of the total Ukrainian trade of goods. During the same period, Ukraine's exports of Chinese goods reached 2.129 billion U.S. dollars, a year-on-year increase of $16.18 \%$, accounting for $4.9 \%$ of Ukrainian exports. The reason why China-Ukraine economic and trade cooperation can develop rapidly is not only the political friendly cooperation between the two countries, but also the strong complementarity of goods between China and Ukraine. Ukraine has the world's largest black land and is suitable for the cultivation of crops. According to reports, in the first 11 months of 2017, the bilateral trade volume of China-Ukrainian agricultural products exceeded one billion US dollars, and the varieties included a large amount of grain, oil and so on. The annual production of Ukrainian soybeans is about 4 million tons, more than half of these which is for export. While in 2016, less than 2,000 tons were exported to China. How to seize the historic opportunities provided by the "Belt and Road Initiative", expand product categories, increase bilateral trade volume, 
and provide new impetus for the rapid development of economic and trade relations between the two countries is a topic of the new era.

\section{Analysis of Competitiveness and Complementarity of Bilateral Trade}

\subsection{Data Sources}

The data onto this paper is derived from the United Nations UN COMTRADE database, using the classification method of the third edition of the Standard International Trade Classification (SITC) (Rev.3). The SITC classification method divides commodities into ten categories, namely from SITC0 to SITC9..In the event of a deficiency in the database, this article will use official data published by both countries.

\subsection{Competitive Analysis of China and Ukraine}

The Trade Intensity Index (TII) was proposed by the economist Brown and later refined by Kiyoshi to measure the degree of trade dependence between the two countries. Its calculation formula is as follows:

$$
T I I_{a b}=\frac{X_{\mathrm{ab}} / X_{a}}{M_{\mathrm{b}} / M_{w}}
$$

Among them, $\mathrm{a}$ and $\mathrm{b}$ represent the two countries to be studied, and $\mathrm{w}$ represents the world market. $X_{\mathrm{ab}} / X_{a}$ Indicates the proportion of exports from country $\mathrm{b}$ to country $\mathrm{b}$ to the total export value of country a, $M_{\mathrm{b}} / M_{w}$ Indicates the total export value of country $\mathrm{b}$ as a percentage of total world exports. $T I I_{\mathrm{ab}}>1$, which shows that the trade links between the two countries are close. $T I I_{\mathrm{ab}}<1$, indicating that the trade links between the two countries are loose.

Table 1 The Trade Intensity Index (TII) between China and Ukraine

\begin{tabular}{|c|c|c|}
\hline years & China's TII with Ukraine & Ukrainian TII with China \\
\hline 2009 & 0.818 & 0.445 \\
\hline 2010 & 0.880 & 0.278 \\
\hline 2011 & 0.823 & 0.330 \\
\hline 2012 & 0.765 & 0.258 \\
\hline 2013 & 0.854 & 0.408 \\
\hline 2014 & 0.741 & 0.468 \\
\hline 2015 & 0.666 & 0.606 \\
\hline 2016 & 0.802 & 0.497 \\
\hline
\end{tabular}

According to the calculation results from Table 1, in 2009-2016, China's The Trade Intensity Index to Ukraine and Ukraine's the Trade Intensity Index to China are both less than 1, showing that the trade links between the two countries are relatively loose. Relatively speaking, China's the Trade Intensity Index with Ukraine is greater than Ukraine's the Trade Intensity Index with China, and there is a certain gap on trade dependence between China and Ukraine. From a dynamic point of view, China's TII against Ukraine has a certain downward trend in 2009-2016, and Ukraine's TII against China has shown an upward trend, especially after 2013. With the further advancement of the "Belt and Road Initiative", the trade links between the two countries will further deepen.

\subsection{Complementary Analysis of China and Ukraine}

\subsubsection{Analysis of intra-industry trade index}

This paper uses the Grubel-Lloyd Intra-Industry Trade Index (G-L Index), which is an index used to measure the extent of intra-industry trade in an industry. The specific calculation formula is:

$$
G L_{i}=1-\frac{\left|X_{\mathrm{i}}-M_{\mathrm{i}}\right|}{\left(X_{i}+M_{i}\right)} .
$$

Among them $X_{i}$ indicates the export value of category i commodities, $M_{i}$ Indicates the import value of category i commodities. The value of $G L_{i}$ is between 0 and 1 , if $G L_{i}>0.5$ indicates that the trade patterns of the two countries are more inclined to intra-industry trade, $G L_{i}<0.5$ indicates that the 
pattern of inter-industry trade predominates.

Table 2 Intra-industry trade index of China and Ukraine

\begin{tabular}{|c|c|c|c|c|c|c|c|c|c|c|}
\hline years & SITC0 & SITC1 & SITC2 & SITC3 & SITC4 & SITC5 & SITC6 & SITC7 & SITC8 & SITC9 \\
\hline 2009 & 0.111 & 0.070 & 0.038 & 0.009 & 0.617 & 0.236 & 0.980 & 0.143 & 0.018 & 0.002 \\
\hline 2010 & 0.133 & 0.193 & 0.036 & 0.063 & 0.017 & 0.500 & 0.206 & 0.149 & 0.012 & 0.096 \\
\hline 2011 & 0.141 & 0.114 & 0.031 & 0.001 & 0.003 & 0.623 & 0.134 & 0.084 & 0.009 & 0.028 \\
\hline 2012 & 0.119 & 0.173 & 0.029 & 0.001 & 0.002 & 0.301 & 0.138 & 0.048 & 0.010 & - \\
\hline 2013 & 0.363 & 0.497 & 0.026 & 0.003 & 0 & 0.132 & 0.036 & 0.039 & 0.009 & 0 \\
\hline 2014 & 0.607 & 0.638 & 0.021 & 0.153 & 0 & 0.112 & 0.062 & 0.098 & 0.028 & 0.794 \\
\hline 2015 & 0.116 & 0.420 & 0.026 & 0.035 & 0 & 0.064 & 0.130 & 0.125 & 0.036 & - \\
\hline 2016 & 0.271 & 0.675 & 0.037 & 0.036 & 0.001 & 0.057 & 0.086 & 0.077 & 0.041 & 0.036 \\
\hline
\end{tabular}

Note:" - " is the missing part of the data

The calculation results from Table 2 show that most of the trade of goods between China and Ukraine is dominated by inter-industry trade. In addition to SITC4, SITC6 in 2009, SITC5 in 2010 and 2011, SITC0, SITC1, and SITC9 in 2014, SITC1 in 2016 shows intra-industry trade, other intra-industry trade indices are below 0.5 , which indicates that between the two countries, the goods are more complementary overall.

According to the factor endowment theory, the complementarity of merchandise trade between the two countries is largely due to the differences in factor endowments between the two countries. The differences in the endowments of capital, natural resources and land between the two countries provide the impetus for future trade cooperation between the two countries. Ukrainian exports to China are mainly concentrated on SITC2 (non-edible raw materials), SITC4 (animal and vegetable oils, fats and waxes), SITC0 (food and live animals). In 2016, exports of these three products accounted for $37.4 \%, 28.77 \%$, and $26.78 \%$. of total Ukrainian export. China's exports to Ukraine are mainly SITC7 (mechanical and transportation equipment), SITC6 (made products by raw materials), and SITC8 (miscellaneous products). In 2016, the three products accounted for $35.95 \%, 26.78 \%$ and $22.76 \%$ of the total exports respectively.It can be seen that the Inter-Industry Trade between China and Ukraine has a clear advantage. Hence there is more room for cooperation between the two countries in the future.

\subsubsection{Analysis of the Revealed Comparative Advantage Index (RCA)}

The Revealed Comparative Advantage Index (RCA) is the most convincing indicator of the competitiveness of a country's industries or products in the international market. The specific calculation formula is as follows:

$$
R C A=\frac{X_{a}^{i} / X_{a}}{X_{w}^{i} / X_{w}}
$$

Where a represents a country and $\mathrm{w}$ represents the world market. $X_{a}^{i} / X_{\mathrm{a}}$ representing the proportion of a country's i-type exported commodities in total a country's total exports, $X_{\mathrm{w}}^{i} / X_{w}$ represents the proportion of the world's i-category export to the world's total exports. If $\mathrm{RCA}<0.8$, it indicates that the country's international competitiveness of the commodity is weak, $0.8 \leq \mathrm{RCA} \leq 1.25$, indicating that such commodities have moderate international competitiveness, $1.25 \leq \mathrm{RCA} \leq 2.5$, and such products are strong in the country. The international competitiveness, RCA $>2.5$, the country's such goods are extremely competitive.

According to this formula, The Revealed Comparative Advantage Index of various commodities in China and Ukraine is calculated (Table 3 and Table 4).

Table 3 Display the Revealed Comparative Advantage Index of various export products of China

\begin{tabular}{|l|l|l|l|l|l|l|l|l|l|l|}
\hline years & SITC0 & SITC1 & SITC2 & SITC3 & SITC4 & SITC5 & SITC6 & SITC7 & SITC8 & SITC9 \\
\hline 2009 & 0.44 & 0.16 & 0.20 & 0.13 & 0.05 & 0.45 & 1.22 & 1.44 & 2.14 & 0.02 \\
\hline 2010 & 0.46 & 0.16 & 0.18 & 0.11 & 0.05 & 0.50 & 1.23 & 1.45 & 2.19 & 0.02 \\
\hline 2011 & 0.47 & 0.16 & 0.18 & 0.10 & 0.05 & 0.56 & 1.30 & 1.47 & 2.29 & 0.02 \\
\hline 2012 & 0.44 & 0.16 & 0.17 & 0.02 & 0.05 & 0.52 & 1.32 & 1.44 & 2.36 & 0.01 \\
\hline 2013 & 0.43 & 0.15 & 0.17 & 0.09 & 0.05 & 0.51 & 1.35 & 1.44 & 2.35 & 0.01 \\
\hline
\end{tabular}




\begin{tabular}{|l|l|l|l|l|l|l|l|l|l|l|}
\hline 2014 & 0.41 & 0.15 & 0.18 & 0.10 & 0.06 & 0.53 & 1.38 & 1.35 & 2.26 & 0.01 \\
\hline 2015 & 0.41 & 0.17 & 0.18 & 0.12 & 0.06 & 0.51 & 1.37 & 1.28 & 2.02 & 0.02 \\
\hline 2016 & 0.44 & 0.19 & 0.18 & 0.15 & 0.05 & 0.52 & 1.36 & 1.26 & 1.99 & 0.04 \\
\hline
\end{tabular}

Table 4 Display the Revealed Comparative Advantage Index of various export products of Ukraine

\begin{tabular}{|l|l|l|l|l|l|l|l|l|l|l|}
\hline years & SITC0 & SITC1 & SITC2 & SITC3 & SITC4 & SITC5 & SITC6 & SITC7 & SITC8 & SITC9 \\
\hline 2009 & 2.48 & 1.84 & 2.80 & 0.40 & 8.55 & 0.54 & 2.87 & 0.49 & 0.34 & 0.15 \\
\hline 2010 & 1.95 & 1.63 & 2.58 & 0.47 & 9.43 & 0.61 & 2.89 & 0.51 & 0.32 & 0.14 \\
\hline 2011 & 1.92 & 1.18 & 2.58 & 0.48 & 7.99 & 0.74 & 2.73 & 0.52 & 0.30 & 0.12 \\
\hline 2012 & 2.88 & 1.21 & 2.57 & 0.08 & 10.12 & 0.69 & 2.51 & 0.58 & 0.28 & 0.13 \\
\hline 2013 & 2.89 & 1.40 & 3.27 & 0.27 & 10.42 & 0.61 & 2.61 & 0.50 & 0.33 & 0.18 \\
\hline 2014 & 3.20 & 1.34 & 3.71 & 0.25 & 13.62 & 0.49 & 2.58 & 0.39 & 0.33 & 0.04 \\
\hline 2015 & 3.83 & 1.67 & 4.23 & 0.13 & 16.45 & 0.45 & 2.25 & 0.33 & 0.32 & 0.08 \\
\hline 2016 & 3.88 & 1.52 & 3.95 & 0.14 & 19.58 & 0.34 & 2.20 & 0.31 & 0.34 & 0.10 \\
\hline
\end{tabular}

According to the calculation results of the data onto Table 3 and Table 4, the distribution of goods with advantages in China and Ukraine is quite different. China's SITC8 (miscellaneous products), SITC7 (mechanical and transportation equipment), and SITC6 (manufactured by raw materials) are highly competitive internationally, and the international competitiveness of other commodities is weak. Ukrainian SITC0 (food and live animals), SITC1 (beverages and tobacco), SITC2 (non-edible raw materials), SITC4 (animal and vegetable oils, fats and waxes), SITC6 (made products by raw materials) have strong international Competitiveness, especially SITC4 (animal and vegetable oils, fats and waxes). The superior commodities of China and Ukraine have no overlapping distribution except SITC6. It can be seen that the industrial structure of the two countries is quite different, and the complementarity of commodities is strong. It provides a broad space for future trade cooperation between the two countries.

\section{Conclusion and suggestion}

By measuring the Trade Intensity Index, the Intra-Industry Trade Index and the Revealed Comparative Advantage Index between China and Ukraine, this paper analyzes the competitiveness and complementarity of the two countries. The analysis shows that although China and Ukraine are competitive in the main markets, they are still dominated by complementarity. In the future, the two countries have greater potential for cooperation in trade. The "One Belt, One Road" initiative aims to promote the orderly and free flow of economic factors, the efficiency of resource allocation, and the deep integration of the market. How to develop trade cooperation between China and Uganda under the background of the "One Belt, One Road" strategy, It is a question worth pondering. In this regard, this paper proposes the following suggestions:

(1) Expanding the scale of trade between China and Ukraine and broadening the types of export products

The trade between China and Ukraine is mainly based on the complementarity of the factor endowments of the two countries, and the structure of export commodities is relatively simple. At present, the trade between the two countries is dominated by inter-industry trade.SITC7 (mechanical and transportation equipment) is a commodity type that is highly dependent on imports in Ukraine. This is exactly the commodity with comparative advantage in China. The two countries should optimize on this basis. Trade structure, broaden the types of export products, and carry out trade cooperation on a larger scale, higher level and deeper level, so as to achieve a win-win situation in cooperation.

(2) Strengthen cooperation in agriculture

Ukraine has the world's largest black land, which is very suitable for the crops cultivation . Thus, its natural resources have great advantages. Compared with Ukraine, China has a rich labor force, abundant capital, and advanced technology. China has a large population and a large demand for grain. The two countries have strengthened cooperation in agriculture and realized the combination of capital, personnel, technology and natural resources, complementing each other's advantages and meeting the interests of both countries. 
(3) Promote direct investment of domestic enterprises in Ukraine, and jointly build Zhongwu Industrial Park

At present, the number of Chinese enterprises investing in Ukraine is relatively small, and the existing investment scale is limited. China and Ukraine should seize the historic opportunity provided by the "Belt and Road Initiative" and learn from the existing experience of industrial park construction to jointly build a industrial park to attract investment from both countries, thus generating good spillover effects.

\section{References}

[1] Tian Ze,Zheng Xiu,Liu Xiaowen.Study on the Competitiveness and Complementarity of SinoAustralian Trade Cooperation under the Background of "Silk Road Economic Belt"[J].Development Research,2016(03):6-9.

[2] Huang Zitong. Research on the Competitiveness and Complementarity of Trade Cooperation between China and Nigeria[J]. China Economic and Trade Guide (Theoretical Edition), 2017(17): 21-23.

[3] Zhang Hong. Risks and Countermeasures of China-Ukraine Cooperation in the "Belt and Road"[J].Peace and Development,2017(04):110-122+128.

[4] Huang Jiaqi. Bilateral Trade Situation between China and Ukraine and Future Trade Prospects[J].Northern Economy,2014(10):76-78. 